\title{
ACADEMIC SUCCESS OF PERSONS WITH VISUAL IMPAIRMENT AND BLINDNESS IN THE TERTIARY SECTOR: EXPLANATORY MODEL
}

\author{
Theekshana Suraweera ${ }^{i}$, \\ Samanthi Bandara, \\ Colinie Wickramarachchi, \\ Navodya Dewage, \\ Tharushi Gunawardana, \\ Nilupuli Nanayakkara, \\ Erandi Yapa, \\ Samantha Thelijjagoda, \\ Ruwan Jayathilaka \\ SLIIT Business School, \\ New Kandy Road, Malabe, 10115, \\ Sri Lanka
}

\begin{abstract}
:
Ensuring universal access to education is an effective and sustainable means of empowering people with visual impairment and blindness. Literature confirms that blindness of a person is not a barrier for learning, yet past research brings about a range of diverse obstacles for productive engagement in education due to universities being designed for the sighted persons. Given that the persons with impairment are looked after comparatively better in the western world than in the developing nations for realising their challenging academic goals. Purpose of this paper is to present the findings of a comprehensive study on the academic work of persons with visual impairment and blindness in the tertiary sector. This population included recent undergraduates and those who have completed a university degree. The two distinct outcomes presented are; (first phase) the critical factors influencing the academic performance of persons with visually impairment and blindness and, (second phase) an explanatory model that characterizes the construct 'the academic performance'. Using a semi-structured questionnaire, purposely selected eleven key informant interviews were utilized for the first phase for the qualitative investigation. Thematic analysis was used as the main method of data analysis. The Second phase employed a sample survey. Fifty respondents who had studied in universities during the 5-year period from 2015-2020 were selected through snow-ball sampling. Exploratory factor analysis was used as the main data analysis technique. The key findings of phase one revealed that external support, physical
\end{abstract}

'Correspondence: email theekshana.s@sliit.lk 
environment, motivation to learn, instructional strategies, ICT and English literacy are major contributory factors to academic performance. The second phase of the quantitative analysis derived five composite factors. Of these, the factor labeled "Motivating influences" appears to be mostly contributing to the academic performance of persons with visual impairment and blindness. While education is a lifelong endeavor of a person, these findings can contribute to make a substantial change in the quality of life of this community in the long run.

Keywords: education, academic, persons with visual impairment and blindness

\section{Introduction}

Visual impairment and blindness are a bodily conditions which in interaction with various barriers hinders a person's full and effective participation in society on an equal basis with others. Thus, people with visual impairment and blindness fall under the broad definition of people with disabilities (PwDs) (UN General Assembly, 2007). Around 2.2 billion people in the world have this form of disability, making it the most prevalent functional disability. Visual impairment and blindness can have serious implications to a person's quality of life (QoL).

As seen by many, social assistance, in cash or kind, is an approach that can uplift the disabled. This strategy, however, could be short-lived and is not a sustainable measure. Nevertheless, education is an effective and sustainable means of empowering people with visual impairment and blindness. It could transform them from a being a tax user to a tax payer. This assertion is well supported with past experience and research findings which indicate that a person's visual impairment or blindness is not a barrier for successful learning. Spinath (2012) reiterates that problems of persons who are visually handicapped are not attributed to concerns of the cognitive domain. Although the absence of a sense of vision of a person encounters certain challenges in information seeking and dissemination, given the right tools and supporting aids he or she can acquire knowledge using the other four senses. Thus, if the person is provided with the right academic environment and assistive technology, a person with visual impairment and blindness would be able to equally compete with their sighted counterparts.

One of the goals of a development agenda is that of ensuring universal access to education. Achieving quality education by 2030 is stated as goal number four in the Sustainable Development Goals (SDGs). Sri Lanka, along with 192 other countries are signatories to this agenda (United Nations, 2015). Thus, education can play a substantial role in narrowing the inequity between and within the community.

Sri Lanka holds a distinctive position in the sphere of education and therefore provides a worthy landscape for investigating into matters related to education of PwDs. This island nation in the Indian ocean is one of the earliest countries in the world that enshrined the right to a free education to all citizens at all levels from primary to tertiary 
(C. W. W. Kannangara, 1943). Furthermore, despite the social and economic downturns over the decades, Sri Lanka maintains a considerably high literacy rate amongst the South Asian countries (Central Bank of Sri Lanka, 2020). However, the situation with respect to education of persons with disabilities is not that attractive. It is reported that out of $1,617,924$ physically or mentally impaired persons who are above 5 years of age, 1,548,684 have not engaged in any educational activity. Only 2,076 of such people have obtained a degree or a higher level in education (Department of Census \& Statistics, 2012). There are approximately one million people experiencing some form of visual incapacity in this country. Within the stream of education, not all students with visual impairment and blindness succeed in university learning. Sri Lankan University Grants Commission data estimates that from 1990-2020, a total of 221,616 persons graduated from universities in Sri Lanka (UGC, 2020). A survey in progress at this time indicates, that from 1966 to 2021, 285 people with visual impairment and blindness have graduated. Furthermore, thus survey reveals that at least 70 such persons are currently undergoing University education (AHEAD, 2021).

Against such odds, the exceptional academic capabilities of persons with blindness are clearly evident with examples including the work of late Professor Wimal Weerakkody, eminent international scholar of University of Peradeniya who was wellknown with his translation of 'The Republic' by Plato to English from the original. Recent statistics confirm that at least ten high achievers of university graduates in Sri Lanka can be cited as super first classes. They have 'topped the batch', in their own fields, like sociology, education, law, languages and education.

Evidence from past literature relating to academic advancement of persons with visual impairment and blindness points to a range of factors effecting academic progress including family background, encouragement and support, physical infrastructure, attitudes, type of education, ICT literacy, and English literacy. While acknowledging the significance of such factors, one can still explore the core limiting cause for persons who are visually handicapped, keeping in mind that the mainstream education systems are designed for sighted individuals. It is observed that there are limited research findings related to the learning of students with visual impairment and blindness at university level (Manitsa and Doikou, 2020). Furthermore, so far, no attempt has been made to logically explain this phenomenon along with the influencing factors in a developing country context. Thus, the aim of this research is to address the above-mentioned gaps in knowledge.

Purpose of this paper is to present the findings of a comprehensive study on the academic work of persons with visual impairment and blindness in the tertiary sector. This population included recent undergraduates and those who have completed a university degree. The two distinct outcomes presented here are; (a) the critical factors influencing the academic performance of persons that are visually impaired and blind and, (b) an explanatory model that characterize the construct 'academic performance'. While education is a lifelong endeavor of a person, these findings can contribute to make 
a substantial change in the QoL of this community in the long run. This paper is organized under five sections including this introduction. Literature review is presented next followed by the methodology, Results of qualitative and quantitative investigations are detailed in section four. A discussion and conclusions are given the last.

\section{Literature review}

The initial literature search was conducted in reputed research journals and databases that included Science Direct, Emerald Insight, Research Gate and Google Scholar, published from 2000 to 2021. Key words used included, Visually Impaired and Blindness, Academic Achievement, Academic Performance, going through the PRISMA model, the factors/dimensions influencing Learning, Disability and Special Needs Education, pointed to 173 articles. Examining the abstracts, 80 papers were excluded and having read the full text, 72 articles were retained as relevant to the study. These included a growing body of literature published globally on the broad topic of academic performance, not limited to people with visual impairment and blindness. It was noted that a growing attention was recently drawn by researchers in Sri Lanka on social issues and QoL of persons with visual impairment and blindness (T. Suraweera and Dunuwila, 2019). This literature review is presented under three main areas namely, education and its consequences, education and QoL and the factors influencing academic performance.

\subsection{Education and its consequence}

Significance of education in all spheres of life is emphasized by Bloom (1987) with the adage "Education is the movement from darkness to light." Accessibility of education needs to be stimulated for the purpose of raising QoL through education, as it signifies the capability of transforming human lives (UNESCO, 2019). The World Educational Conference (2000) declaring the "Education for all" framework for action illuminates that every educational opportunity should be designed to meet the basic learning needs of every person despite being a child, youth or an adult (UNESCO, 2000). It is also observed that the constitution of the Democratic Socialist Republic of Sri Lanka also guarantees and thereby bound to fulfill children's right for education since it improves the QoL (20th Amendment: Constitution, 2020).

An 'educated person' is characterized by his or her 'academic performance', which can be described as the highest level of education that the person has successfully completed. Spinath (2012) refers to 'academic performance' as one of the significant determinants of defining the magnitude of the future of a person based on completion of educational benchmarks regardless of their physical differences. The successful completion of any form of education means the achievement of learning objectives validated through the assessment of acquired knowledge, skills and competencies. In the domain of general education basically two aspects are addressed, namely, academic curriculum dealing with subject matter and co-curriculum covering life skills such as 
communication and personality. However, for the persons with visual impairment and blindness an extended co-curriculum has been included to cover additional learning areas such as orientation and mobility, compensatory skills and social interaction.

Consequences of education are many fold. It contributes to the improvement of the human condition through better knowledge, health, living conditions, social equity and productivity. "Education is expected to foster social progress through four different but interrelated purposes: humanistic, through the development of individual and collective human virtues to their full extent; civic, by the enhancement of public life and active participation in a democratic society; economic, by providing individuals with intellectual and practical skills that make them productive and enhance their and society's living conditions; and through fostering social equity and justice." (Spiel et al., 2018).

\subsection{Education and quality of life}

In the recent past, much attention has been drawn to studies on understanding academic performance and its effect for QoL among persons with various physical and other impairments - generally referred to as persons with disabilities. Higher levels of educational attainment have a positive effect on a person's QoL realized through better occupational prospects and higher income (Edgerton et al., 2012). This assertion is equally applicable to education of persons with visual impairment and blindness. Many people with various disabilities deemed to be a liability to national economies have been excluded from society for not making a substantial contribution to it. (C. Wickramaarachchi et al., 2021). Certain past studies have shown that people with visual impairment and blindness have struggled in diverse means for achieving their academic goals. These include mobility, psychological, social and economic concerns (T. Suraweera et al., 2021). While such matters influence QoL, facilitating inclusive education with a right academic environment is observed as a key determinant for improved QoL (T. Suraweera and Dunuwila, 2019).

\subsection{Factors influencing academic performance}

Realizing academic goals is challenging for people with visual impairment and blindness, if the right environment and the appropriate assistive aids are not provided. A number of factors that have an effect on academic performance of students in general, and for people with disabilities in particular have been cited in literature. In this respect, the work of Maingi-Lore (2016) stands out as relevant to this study, where the key determinants influencing academic progress of University undergraduate with special needs have been identified. The conceptual model adopted in a study proposes six factors that could be used as the basis for investigation of this research. The factors are family background, external parties, physical infrastructure, assistive devices and technologies, instructional strategies, motivation, and English and IT literacy. 


\section{A. Family background}

Family background refers to the kind of family the person hails from, and it relates to such things as parents educational status, their social and racial origins, financial status, or the type of work experience the family members pursue (Davis, 2021). The family background is considered as an important element influencing the academic performance of all students. This factor along with their socio-economic status play a crucial role in his or her academic development and for most activities and functioning of all the students and also students with special needs (Hijazi and Naqvi, 2006, MaingiLore, 2016). Significant and positive relationships between academic performance and conducive home environment have been reported (Shahzadi and Ahmad, 2011).

\section{B. External parties}

A recent study on challenges and opportunities facing students with visual impairment in inclusive education by Yihun and Belay (2020) emphasized that the students with visual challenges constantly need someone's assistance. As such, peer encouragement is very much essential to visually impaired students in different situations (Manitsa and Doikou, 2020). The acceptance from the school community assisted them to establish friendships and increased social interactions and relationships. Self-determination theory suggests that supportive teaching can trigger students' psychological needs for competence, autonomy, and relatedness that brings a positive influence on their motivation to engage in learning (Deci and Ryan, 2000).

Luthar (2000) and Masten (2001) revealed social support as protective factors in the context of family, school and community for coping with social functioning and social interactions for needy students. Bernard (1991) further revealed that the students' participation on academic progress and socio-emotional growth can be improved through relationships with attentive teachers and peers, as well as through social support and resources. This finding is further verified by Celeste and Grum (2010) indicating that the students with visual impairment can improve future independent living with the support received from teachers and peers at school. According to Anne G. Danielsen et al, (2009) peer support for problem-solving can encourage learning. All this including teacher support leads to a satisfying school experience.

Lindsay and McPherson (2012) has found that self-esteem and self-confidence could be positively impacted through the maintenance of student's social relationships and friendships. In addition, Pavri and Monda-Amaya (2001) has found that acceptance and a feeling of belonging to the school environment along with emotional and instrumental support from teachers and peers provides a positive influence to students' well-being. Further, these are considered fundamental components of inclusive education. As per Carter et al. (2015), peer support arrangements via the provision of academic and social support despite the disabilities, help the students with severe disabilities in inclusive secondary classrooms. 
Support provided by the staff (teachers, and members of the staff and support services) towards overall learning enhancement of the students with visual impairment is acknowledged considerably by literature. Specially in school settings, staff support towards building peer relationships (West et al., 2004), development of a sense of acceptance (Bodaghi et al., 2016b) and helping for problem solving (Nees and Berry, 2013) is satisfied. However, staff support at university level though highly signified, needs improvement according to the students with visual impairments (Bodaghi et al., 2016a, West et al., 2004).

The level of social support from family and friends (including 'significant others') provided to adolescents with visual impairments was significantly higher compared to the sighted, was reported by a case study of Hadidi et al. (2014).

Morelle and Tabane (2019) emphasized that even within the school education setup, involvement of teachers and parents to promote inclusiveness of students with visual impairment and blindness into the mainstream, is important. Furthermore, the teachers should be trained and facilitating physical resources provided for maintaining a healthy environment for the students with visual impairment and blindness.

These literature outcomes emphasize the influence of parties external to the person for realizing academic progress. These parties may include peers, friends and relatives, teachers and other people working in the academic environment, with groups or institutions also providing some form of support.

\section{Physical infrastructure}

In a broad sense the physical environment is where people live, learn, work, and play. Its elements include the built environment (i.e. the man-made infrastructure such as roads and buildings) and the natural setting. People interact with their physical environment through several elements and for persons with visual impairment and blindness, it mainly affects their orientation and mobility, travel, and transport.

United Nations (2006) states that "persons with disabilities are entitled to a barrier-free and disability-friendly environment enabling them to have access to buildings, roads and other social amenities along with assistive devices and other equipment to promote their mobility". Within the context of this mobility friendly physical infrastructure, Pathrose and Ramaa (2020) pointed out that in order to enable an effective learning process, it is important to have special educational services, special infrastructure or learning facilities within the institutions. However, Maingi-Lore (2016) showed that although physical facilities are important, their relative importance for academic performance is less significant. Their findings discovered that though efforts had been made to make the buildings and path ways accessible to students with special needs, many improvements are needed to make the environment reasonably comfortable to PwDs. 


\section{Assistive devices and technologies}

Assistive devices and technologies are used to enhance the functioning and performance of daily living skills and are aimed at improving independent living of persons with visual impairment and blindness. These appliances include devices to fortify their mobility, education, reading, writing, daily living, and communication (Senjam, 2019a). Senjam (2019b) has identified a range of assistive devices available for visually challenged people for education. These include large print books, multiple window typoscope, optical magnifiers, DAISY books, braille reading materials, refreshable braille display, and screen readers. Nees and Berry (2013) has shown that, the use of assistive technology enhances access to learning while Datta and Palmer (2015) has provided evidence indicating that the use of adaptive technology and inclusive curriculum can have a positive impact on the learning of students with visual impairment.

\section{E. Instructional strategies}

Teachers use various techniques to help students' learning and make them independent and strategic learners. These strategies in turn become the students' learning strategies when they select and adhere to the approaches fit to their needs (Alberta, 2002). Evidence from past literature show that fitting the teaching struggles to the needs for students with particular disabilities such as visual incapacities, is crucial for achieving the targeted levels of academic progress. Such measures include not only the curricula being designed appropriately but also that the teaching methods used are appropriate and inclusiveness is promoted (Kamal et al., 2014, Maingi-Lore, 2016, Otyola et al., 2017).

\section{F. Self-motivation}

Self-determination and self-motivation of the undergraduates are positively and significantly related with academic performance (S. Fernando, 2017). Abate (2020) confirmed the above fact that the students who spend more of their time studying with much effort do well than others who do not. Shahzadi and Ahmad (2011) suggest that improved study habits with good motivation lead to improved academic interaction, which would lead to better academic performance. Visual impairments can also affect negatively on students' motivation to engage in learning tasks (Pinquart \& Pfeiffer (2012). Kain (2016) noted that there was no significant difference in the study habits between students with visual impairment and blindness (studying in special schools) and sighted students (studying in regular schools). It is shown that through boosting the students' motivation by supporting their needs can also enhance the behavioral and emotional engagement during education (Fredricks et al., 2004). This assertion is confirmed by Haakma et al. (2018).

\section{G. Literacy of English and IT}

As the topic indicates, the two factors that could influence academic performance are 'English Literacy' and 'Literacy of Information and Communication Technology (ICT)'. 
Previous research has found a relationship between students' English proficiency and their overall academic performance (Ghenghesh, 2014). Competency in English for success in the academic activities in today's world is important since it is the most commonly spoken language in the world (Nishanthi, 2018). This factor is of vital significance if the medium of instructions is English. Need for becoming literate in English for students learning in a medium other than English in a non-English sociocultural background is uncertain. However, since advanced academic literature is not freely available in most native languages, and in particular for the students with visually impairment and blindness who depend on 'talking books' and computer assisted readable formats, English literacy could play a significant role.

Becoming ICT literate and being competent in certain technologies would be of similar importance for the students with visual impairment and blindness in universities. Irrespective of their visual capacities, the young of today are surrounded and immersed in technology. IT is used in education in diverse proportions. Thus, the ability to operate smartphones, computers and tablets is important for every student (Santos and Ramos, 2019). In addition, previous studies have shown that having access to and using a home computer, having a computer area in the classroom, having software, and having computers in school are all positively correlated with improved academic performance (Judge, 2005).

It is seen that while English and ICT would have an influence in studies their role is supportive rather than a core requirement for academic progress of persons with visual impairment and blindness, in particular in countries where English is not the medium of instruction.

\section{Material and Methods}

Since this study deals with both exploratory and explanatory aspects of university academic work of persons with visual impairment and blindness, a mixed methodology was used. Therefore, subsequent to the literature review, a qualitative investigation was adopted as the first phase, aimed at identifying the key factors influencing the academic progress of persons with visual impairment and blindness. The findings of the first phase were taken as the basis for the second phase, which was a quantitative investigation. The second phase was aimed at developing an explanatory model of the research construct of interest, 'academic performance of persons with visual impairment and blindness'.

Due ethical clearance for the study was obtained from the ethical clearance board of the Faculty of Postgraduate and Research of SLIIT. The study population comprised persons with visual impairment and blindness, who have learning experience in state Universities in Sri Lanka. Key informant interviews using a semi-structured questionnaire as the guide was the main method of data collection for the first phase. Eleven (11) purposely selected persons representing diverse segments was the population. A gender mix of interview participants was maintained with seven males 
and four females between 20 to 45 years of age. With the prior consent of the respondents, interviews were carried out via phone calls and zoom meetings and the proceedings were audio recorded. The recorded proceedings were transcribed verbatim and translated into English. Thematic analysis was used as the main method of data analysis. As a prelude to qualitative analysis, a 'word cloud' visual representation was derived using the English version of the interview transcripts.

Second phase of the investigation was a sample survey of both graduates and undergraduates who are visually impaired and blind, from four (4) state universities in Sri Lanka. A pretested questionnaire was developed based on the factors identified from past literature and results of the qualitative phase of investigation as outlined above. The questionnaire comprised 33 Likert scale statements aimed at seeking the participants opinion relevant to the six explanatory dimensions, namely physical infrastructure (5), family and peer support (6), support from external parties (6), instructional strategies (6), self-motivation (7) and competency in English and IT literacy (3). The number of statements within each dimension is indicated within brackets.

Using snow-ball sampling method, 50 respondents were selected composed of people who have been studying in universities during the 5-year period from 2015-2020. Given that the estimated total population of persons with visual impairment and blindness who have undergone university education in Sri Lanka is around 400, the sample size was deemed reasonable. The data extracted through Google forms were systematically organized in Excel and SPSS 27.0 version was used to conduct factor analysis. Exploratory factor analysis was used as the main data analysis technique in the second phase of investigations.

\section{Results}

This section presents the results of the two main phases of investigation followed by a discussion combining the outcomes of both segments.

\subsection{Phase one: Identification of key dimensions}

As indicated earlier, the qualitative phase of the investigation was aimed at determining the key dimensions influencing the academic performance of people with visual impairment and blindness. The word cloud visualization (see Figure 1) brings about a number of phrases that could guide the identification of keywords of the thematic analysis. 


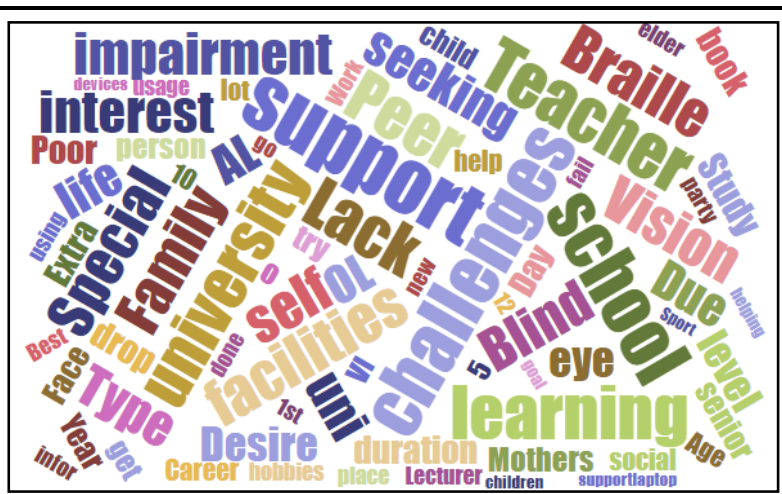

Figure 1: WordCloud representation of qualitative responses

They are, family, support, desire, learning, facilities, challenges, peers, and university. As a result of those keywords identified from the word cloud visualization, through thematic analysis, the below mentioned factors were recognized as key determinants of academic achievement of persons with visual impairment and blindness at the university level. The keywords highlighted also used as a preliminary guide for the thematic analysis process. Findings of the thematic analysis are summarized in Table 1 .

Table 1: Evidences derived from the thematic analysis

\begin{tabular}{|c|c|}
\hline $\begin{array}{l}\text { Factors derived from } \\
\text { qualitative investigation }\end{array}$ & Evidence (Selected excerpts from interview transcripts) \\
\hline $\begin{array}{l}\text { External support } \\
\text { (Family and peers) }\end{array}$ & $\begin{array}{l}\text { "Words cannot describe the support I received from my parents and teachers for } \\
\text { my success in education. ... Their motivation (and) helps in doing my day today } \\
\text { activities were great... (They) helped me by reading books and other study } \\
\text { materials for me."- (Severely impaired female graduate) } \\
\text { "My friends really helped me a lot when it comes to my studies. (A recent, first } \\
\text { class graduate who is blind) }\end{array}$ \\
\hline Physical environment & $\begin{array}{l}\text { "We received special facilities like the science lab from school. It's a separate one, } \\
\text { and it helped a lot. But in university, it was very difficult to adjust because we } \\
\text { didn't have any special facilities." (Undergraduate who is blind) }\end{array}$ \\
\hline Motivation to learn & $\begin{array}{l}\text { "If you are confident that you can, and if you can do what you determine to do, } \\
\text { then you will not fail. This thinking in me became the force for me to do well in } \\
\text { my studies." (A university undergraduate, blind) }\end{array}$ \\
\hline Instructional strategies & $\begin{array}{l}\text { "My school used some effective teaching strategies such as geographical maps } \\
\text { made from clay, which is easily recognizable and that was very helpful for us to } \\
\text { do well in our studies..." (A severely impaired undergraduate) } \\
\text { "In my school which was a mainstream school, teachers paid special attention to } \\
\text { explain lessons, illustrate pictorial representations using different strategies." } \\
\text { (A graduate) } \\
\text { "Some relevant books were not there and not in audio format either." (A blind } \\
\text { undergraduate) }\end{array}$ \\
\hline English and IT literacy & $\begin{array}{l}\text { "Having a sound IT knowledge with a certain level of English contributed a lot } \\
\text { to do my studies very well. I used the internet to get international news, } \\
\text { gathering information and getting knowledge on various information systems, } \\
\text { technologies. It's worth cannot be put into words." (A university } \\
\text { undergraduate, blind) }\end{array}$ \\
\hline
\end{tabular}


The resulting themes of the analysis forms the key factors that would affect the academic performance of persons with visually impaired and blindness in the University system (Suraweera, 2021). It was noted that the academic needs of people with visual impairment and blindness in general are associated with information behavior, which include information seeking for learning and information dissemination associated with examinations. Most of these persons have been using Braille as the main communication mode and a trend is observed towards moving on to the use of computers and screen reading software.

The factor labeled "External Support" is directly associated with the academic process of this community stemming from mobility and orientation issues and problems of information seeking. Discussions revealed that those who have mitigated the challenges related to reading printed material have got direct support from their peers. Parental support not only for moving around and other martial needs, but also towards motivation to succeed were highlighted.

Several aspects of the "Physical Environment" could influence the academic processes. Basic 'disability friendly' infrastructure is helpful to move around and to have access to lecture rooms etc. In attending the 'face-to-face' lectures also, the visually impaired and blind persons need certain special arrangements.

"Motivation" to learn has been highlighted by several persons who have had successful results in the academic process. Intrinsic motivation emerging from within the person is seen to be the key ingredient in this respect.

Instructional strategies including the modes of teaching (i.e. physical and online) as well as the teaching style also play a major role in academic success of persons with visual impairment and blindness.

It was noted that almost all those persons examined study in Universities in the Sinhala medium (one of the languages used in Sri Lanka). Hence, competency in English is required for using computers for information seeking and other communication related purposes. ICT skills are also applicable in the same manner.

\subsection{Phase Two: Deriving the factor model}

As detailed in the methodology section, exploratory Factor Analysis (EFA) was used as the data reduction technique while Principal Component Analysis (PCA) has created index variables, called components. Accordingly, second-higher order factor analysis was applied which consists of a 33-factor structure. Before moving onto the factor analysis, the row data set was subjected to a process of data organization which included coding, data cleaning and testing to ascertain the suitability of data for factor analysis. Accordingly, sample adequacy, normality and linearity, outliers and correlation among the items were examined. 


\section{A. Data organization}

\section{a. Reliability of data}

Data reliability was examined on the basis of internal consistency of each dimension computing the Cronbach's alpha (see Table 2). Given that the Cronbach's alpha values reached above 0.7 , data can be accepted as reliable.

Table 2: Reliability of the data

\begin{tabular}{|l|c|c|}
\hline Dimension (as per initial conceptualization) & No. of items & Cronbach's Alpha \\
\hline Physical infrastructure & 5 & 0.787 \\
\hline Family and peers & 6 & 0.908 \\
\hline External parties & 6 & 0.916 \\
\hline Instructional strategies & 6 & 0.900 \\
\hline Motivation & 7 & 0.968 \\
\hline English and IT literacy & 3 & 0.787 \\
\hline
\end{tabular}

\section{b. Sample adequacy}

The sampling adequacy test of Kaiser-Meyer-Olkin measure (KMO) resulted in a value of 0.842. This is above the commonly applicable acceptance level of 0.6 and hence the sample size could be accepted as adequate (see Table 3).

Table 3: Sampling adequacy test

\begin{tabular}{|l|l|c|}
\hline \multicolumn{2}{|l|}{ Kaiser-Meyer-Olkin measure of sampling adequacy } & 0.842 \\
\hline Bartlett's Test of Sphericity & Approx. Chi-Square & 2301.988 \\
\hline & df & 528 \\
\hline & Sig. & .000 \\
\hline
\end{tabular}

The anti-image correlation matrix show that all the diagonal elements are greater than 0.5 and all off diagonal elements are different from zero (and greater than 0.3 ). The Bartlett's test of sphericity, which compares the observed correlation matrix to the identity matrix was found to be statistically significant $(\chi 2(528)=2301.99, p<.05)$. Further, all communalities extracted by Principal Component Analysis (PCA) were greater than 0.30. Each variable has therefore shared some common variance. This indicates that the variance of each variable was explained adequately by the extracted factors. Overall, all 33 items were accepted as suitable for factor analysis.

\section{B. Factor analysis}

The initial factor analysis resulted five components with Eigen values greater than 1, (see Table 4). These five components are observed to be explaining the variances with $61.2 \%$, $9.5 \%, 5.4 \%, 4.3 \%$ and $3.2 \%$ respectively. Cumulative variance was $83.45 \%$ and it can be inferred that the five factors adequately explain the construct in hand. 
Theekshana Suraweera, Samanthi Bandara, Colinie Wickramarachchi, Navodya Dewage, Tharushi Gunawardana, Nilupuli Nanayakkara, Erandi Yapa, Samantha Thelijjagoda, Ruwan Jayathilaka ACADEMIC SUCCESS OF PERSONS WITH VISUAL IMPAIRMENT AND BLINDNESS IN THE TERTIARY SECTOR: EXPLANATORY MODEL

\begin{tabular}{|c|c|c|c|c|c|c|c|c|c|}
\hline \multicolumn{10}{|c|}{ Table 4: Total variance explained } \\
\hline \multirow{2}{*}{$\begin{array}{l}\tilde{0} \\
\tilde{0} \\
0 \\
0 \\
0 \\
0\end{array}$} & \multicolumn{3}{|c|}{$\begin{array}{l}\text { Initial } \\
\text { eigen } \\
\text { values }\end{array}$} & \multicolumn{3}{|c|}{$\begin{array}{c}\text { Extraction } \\
\text { sums of } \\
\text { squared loadings }\end{array}$} & \multicolumn{3}{|c|}{$\begin{array}{c}\text { Rotation } \\
\text { sums of } \\
\text { squared loadings }\end{array}$} \\
\hline & Total & $\begin{array}{c}\text { \% of } \\
\text { variance }\end{array}$ & $\begin{array}{c}\text { Cumulative } \\
\%\end{array}$ & Total & $\begin{array}{c}\% \text { of } \\
\text { variance }\end{array}$ & $\begin{array}{c}\text { Cumulative } \\
\%\end{array}$ & Total & $\begin{array}{c}\% \text { of } \\
\text { variance }\end{array}$ & $\begin{array}{c}\text { Cumulative } \\
\%\end{array}$ \\
\hline 1 & 20.199 & 61.209 & 61.209 & 20.199 & 61.209 & 61.209 & 12.954 & 39.253 & 39.253 \\
\hline 2 & 3.149 & 9.544 & 70.753 & 3.149 & 9.544 & 70.753 & 5.560 & 16.849 & 56.102 \\
\hline 3 & 1.785 & 5.409 & 76.161 & 1.785 & 5.409 & 76.161 & 3.270 & 9.910 & 66.012 \\
\hline 4 & 1.404 & 4.255 & 80.417 & 1.404 & 4.255 & 80.417 & 2.895 & 8.774 & 74.786 \\
\hline 5 & 1.003 & 3.038 & 83.455 & 1.003 & 3.038 & 83.455 & 2.861 & 8.669 & 83.455 \\
\hline
\end{tabular}

This initial extraction of factors was followed by the orthogonal rotation (Varimax with Kaiser Normalization). Thereby five factors with a cumulative variance of $83.45 \%$ with primary factor loadings considerably higher than 0.5 were identified (see Table 5). The gist of Likert scale statements presented to the respondents for self-assessment related to their university education are presented in the 'item' column.

Table 5: Rotated component matrix

\begin{tabular}{|c|c|c|c|c|c|c|}
\hline \multirow{2}{*}{ No. } & \multirow{2}{*}{ Item } & \multicolumn{5}{|c|}{ Component } \\
\hline & & 1 & 2 & 3 & 4 & 5 \\
\hline 1 & $\begin{array}{l}\text { Ability to use assistive devices that the student is } \\
\text { used primarily. }\end{array}$ & 0.866 & & & & \\
\hline 2 & $\begin{array}{l}\text { Ability to use assistive devices that the student is } \\
\text { used in addition to the primary device. }\end{array}$ & 0.834 & & & & \\
\hline 3 & $\begin{array}{l}\text { Motivational support of family members and } \\
\text { external parties. }\end{array}$ & 0.785 & & & & \\
\hline 4 & $\begin{array}{l}\text { Other support (e.g. financial and martial) of family } \\
\text { members and external parties. }\end{array}$ & 0.788 & & & & \\
\hline 5 & $\begin{array}{l}\text { Skills of smart phone usage for access and sharing } \\
\text { information. }\end{array}$ & & & & & 0.674 \\
\hline 6 & $\begin{array}{l}\text { Skills of Internet usage for access and sharing } \\
\text { information. }\end{array}$ & & & & & 0.780 \\
\hline 7 & English literacy as a facilitator for university studies. & & & & & 0.652 \\
\hline 8 & Self-motivation for university studies. & 0.751 & & & & \\
\hline 9 & Self-motivation for learning English. & & 0.579 & & & \\
\hline 10 & $\begin{array}{l}\text { Smartness (intelligence, confidence and decision } \\
\text { making) for leaning in the University. }\end{array}$ & 0.870 & & & & \\
\hline 11 & Hardworking nature towards education. & 0.840 & & & & \\
\hline 12 & ‘Never give up' behavior towards education. & 0.852 & & & & \\
\hline 13 & 'NOT postponing' behavior on academic work. & 0.841 & & & & \\
\hline 14 & How passionate you are of the subjects studied? & 0.860 & & & & \\
\hline 15 & Satisfaction towards teaching style (of lecturers). & 0.705 & & & & \\
\hline 16 & Satisfaction towards teaching in physical class room. & 0.800 & & & & \\
\hline 17 & $\begin{array}{l}\text { Satisfaction on physical resources in the university } \\
\text { premises. }\end{array}$ & 0.681 & & & & \\
\hline
\end{tabular}


Theekshana Suraweera, Samanthi Bandara, Colinie Wickramarachchi, Navodya Dewage,

Tharushi Gunawardana, Nilupuli Nanayakkara, Erandi Yapa, Samantha Thelijjagoda, Ruwan Jayathilaka ACADEMIC SUCCESS OF PERSONS WITH VISUAL IMPAIRMENT AND BLINDNESS IN THE TERTIARY SECTOR: EXPLANATORY MODEL

\begin{tabular}{|c|c|c|c|c|c|}
\hline 18 & $\begin{array}{l}\text { Satisfaction on your accommodation during } \\
\text { university life. }\end{array}$ & 0.689 & & & \\
\hline 19 & Satisfaction on classroom arrangements. & 0.661 & & & \\
\hline 20 & Satisfaction on exam arrangements. & 0.517 & & & \\
\hline 21 & Satisfaction on lecture material provided. & & 0.944 & & \\
\hline 22 & $\begin{array}{l}\text { Satisfaction on opportunities to access for extra } \\
\text { study materials (e.g. library). }\end{array}$ & & 0.901 & & \\
\hline 23 & $\begin{array}{l}\text { Satisfaction on accessibility for study related } \\
\text { equipment (e.g. Laptop, Desktop, Recorder, } \\
\text { Typewriter, Braille \& Slate). }\end{array}$ & & & & 0.630 \\
\hline 24 & $\begin{array}{l}\text { Support for studies by the peers with visual } \\
\text { impairment and blindness. }\end{array}$ & & & & 0.906 \\
\hline 25 & $\begin{array}{l}\text { Support for University social life by the peers with } \\
\text { visual impairment and blindness. }\end{array}$ & & & & 0.819 \\
\hline 26 & Support for studies by the sighted peers. & 0.712 & & & \\
\hline 27 & $\begin{array}{l}\text { Support for University social life by the sighted } \\
\text { peers. }\end{array}$ & 0.724 & & & \\
\hline 28 & $\begin{array}{l}\text { Support for studies by the University teaching staff } \\
\text { (e.g. lecturers, professors). }\end{array}$ & 0.669 & & & \\
\hline 29 & $\begin{array}{l}\text { Support for studies by the other academic } \\
\text { (supporting) staff of resource centers in the } \\
\text { university. }\end{array}$ & 0.496 & & & \\
\hline 30 & $\begin{array}{l}\text { Support for studies of non-academic staff of the } \\
\text { university. }\end{array}$ & & 0.572 & & \\
\hline 31 & $\begin{array}{l}\text { Support for studies by the organizations dedicated } \\
\text { for visually impaired and blind. }\end{array}$ & & & 0.677 & \\
\hline 32 & $\begin{array}{l}\text { Financial support received from the Government } \\
\text { (and University). }\end{array}$ & & & 0.649 & \\
\hline 33 & $\begin{array}{l}\text { Support for studies by the people and institutes } \\
\text { outside the university. }\end{array}$ & & & 0.727 & \\
\hline
\end{tabular}

Correlation matrix of the five factors extracted is given in Table 6 . It can be seen that all relevant correlation coefficients, except one (0.919) are below 0.8. Thus, no multicollinearity issues are observed in the factors derived.

Table 6: Component correlation matrix

\begin{tabular}{|l|c|c|c|c|c|}
\hline Component & $\mathbf{1}$ & $\mathbf{2}$ & $\mathbf{3}$ & $\mathbf{4}$ & $\mathbf{5}$ \\
\hline 1 & 0.775 & 0.406 & 0.316 & 0.242 & 0.276 \\
\hline 2 & -0.402 & 0.793 & 0.333 & -0.200 & -0.242 \\
\hline 3 & -0.244 & -0.042 & 0.171 & 0.919 & -0.257 \\
\hline 4 & -0.308 & 0.320 & -0.466 & 0.224 & 0.732 \\
\hline 5 & -0.289 & -0.321 & 0.737 & -0.085 & 0.514 \\
\hline $\begin{array}{l}\text { Extraction method: Principal component analysis } \\
\text { Rotation method: Varimax with Kaiser normalization }\end{array}$ \\
\hline
\end{tabular}


Labeling the five factors so extracted was guided by the past literature findings and discussion outcomes of the key informant interviews. Table 7 presents the factors labels, and a summary of their descriptive statistics and reliability scores.

Table 7: Descriptive statistics for extracted factor (Sample size $\mathrm{N}=50$ )

\begin{tabular}{|c|c|c|c|c|c|}
\hline Factor labels & $\begin{array}{l}\text { Number } \\
\text { of items }\end{array}$ & Mean (SD) & $\begin{array}{c}\text { Skewness } \\
\text { (Z score) }\end{array}$ & $\begin{array}{l}\text { Kurtosis } \\
\text { (Z score) }\end{array}$ & $\begin{array}{c}\text { Cronbach's } \\
\alpha \\
\end{array}$ \\
\hline $\begin{array}{l}\text { 1. } \begin{array}{l}\text { Motivational } \\
\text { influences }\end{array} \\
\end{array}$ & 20 & $3.92(1.078)$ & -2.86 & 0.08 & 0.985 \\
\hline $\begin{array}{l}\text { 2. Support } \\
\text { for learning }\end{array}$ & 4 & $3.54(1.010)$ & 0.82 & -2.02 & 0.873 \\
\hline $\begin{array}{ll}\text { 3. } & \text { External } \\
& \text { Assistance } \\
\end{array}$ & 3 & 3.49 (1.022) & -0.14 & -1.85 & 0.806 \\
\hline $\begin{array}{ll}\text { 4. } & \text { Peer and } \\
& \text { Physical Support }\end{array}$ & 3 & $3.13(0.765)$ & -0.35 & 0.75 & 0.804 \\
\hline $\begin{array}{l}\text { 5. Access to } \\
\text { information }\end{array}$ & 3 & $3.47(0.911)$ & -2.71 & 1.40 & 0.787 \\
\hline
\end{tabular}

Note: SD-Standard deviation

Composite scores for each factor were computed based on the mean of items' primary factor loading. Mean score of a factor is an indication of the extent of influence on academic performance of the graduates with visual impairment and blindness. The highest mean score of 3.92 of the factor labeled "Motivating Influences" appear to be mostly contributing to the academic performance of persons with visual impairment and blindness. It observed that the influence of the factor labeled "Peer and Physical Support" to academic performance relatively low, and the score distribution is positively skewed. The $\mathrm{Z}$ scores for skewness and kurtosis of composite score are within acceptance level $(+/-3.29$ for $n \geq 50)$, the data is assumed to be normally distributed (Mishra et al., 2019).

Table 8 shows positive correlation coefficient of composite scores which are significant. Importantly, all the coefficients lie between accepted values of coefficients that is greater than .3 and less than .8. This indicates strong association and approximately no multi-collinearity.

Table 8: Correlation matrix of composite scores

\begin{tabular}{|c|c|c|c|c|c|}
\hline Factor & $\begin{array}{c}\text { Motivational } \\
\text { influences }\end{array}$ & $\begin{array}{l}\text { Support for } \\
\text { learning }\end{array}$ & $\begin{array}{c}\text { External } \\
\text { assistance }\end{array}$ & $\begin{array}{l}\text { Peer and } \\
\text { physical } \\
\text { support }\end{array}$ & $\begin{array}{l}\text { Access to } \\
\text { information }\end{array}$ \\
\hline $\begin{array}{l}\text { 1. Motivational } \\
\text { influences }\end{array}$ & 1 & & & & \\
\hline $\begin{array}{l}\text { 2. Support for } \\
\text { learning }\end{array}$ & $0.629^{* * *}$ & 1 & & & \\
\hline $\begin{array}{l}\text { 3. External } \\
\text { assistance }\end{array}$ & $0.723^{* * *}$ & $0.641^{* *}$ & 1 & & \\
\hline
\end{tabular}




\begin{tabular}{|l|l|l|l|c|c|}
\hline $\begin{array}{l}4 . \\
\begin{array}{l}\text { Peer and } \\
\text { physical } \\
\text { support }\end{array}\end{array}$ & $0.573^{* *}$ & $.382^{* *}$ & $0.393^{* *}$ & 1 & \\
\hline $\begin{array}{l}5 . \\
\text { Access to } \\
\text { information }\end{array}$ & $0.684^{* *}$ & $0.349^{*}$ & $0.403^{* *}$ & $0.410^{* *}$ & 1 \\
\hline
\end{tabular}

**. Correlation is significant at the 0.01 level (2-tailed)

*. Correlation is significant at the 0.05 level (2-tailed).

The quantitative analysis confirms that five composite factors extracted through a thirtythree (33) item measure are able to explain the construct 'academic achievement of the persons with visual impairment and blindness in the tertiary sector'. These five composite factors demonstrate internal consistency and follow an approximately normal distribution. These five composite score data can be used for parametric statistical analysis in future studies.

Phase one results were used as outlined in the methodology section. As detailed in the methodology section, exploratory Factor Analysis (EFA) was used as the data reduction technique while Principal Component Analysis (PCA) has created index variables, called components. The study accordingly has applied second-higher order factor analysis

\section{Discussion and Conclusion}

As outlined earlier the overall objective of this study is to understand the factors influencing academic achievement of persons with visual impairment and blindness in the University sector.

While the conceptual framework based on past literature directs to six (6) factors, qualitative phase of investigation pointed to five factors. Furthermore, the quantitative analysis brought them to five composite factors that are somewhat different and are briefly outlined in Table 9 .

Table 9: The factors affecting academic achievement

of persons with visual impairment and blindness

\begin{tabular}{|l|l|l|l|}
\hline $\begin{array}{l}\text { Factors based on the } \\
\text { conceptual framework }\end{array}$ & $\begin{array}{c}\text { Qualitative } \\
\text { results } \\
\text { (Factor labels) }\end{array}$ & $\begin{array}{c}\text { Quantitative } \\
\text { results } \\
\text { (Factor labels) }\end{array}$ & \multicolumn{1}{|c|}{ Notes } \\
\hline $\begin{array}{l}\text { Physical infrastructure } \\
\text { (Accessibility related } \\
\text { infrastructure facilities } \\
\text { and academic related } \\
\text { equipment }\end{array}$ & $\begin{array}{l}\text { Physical } \\
\text { environment } \\
\text { (Accessibility }\end{array}$ & $\begin{array}{l}\text { Refer the note } \\
\text { related } \\
\text { infrastructure } \\
\text { facilities only) }\end{array}$ & $\begin{array}{l}\text { Accessibility related- physical } \\
\text { infrastructure is absorbed into } \\
\text { 'motivational influences' while } \\
\text { academic related physical } \\
\text { resources is extracted by 'peer } \\
\text { and physical support'. }\end{array}$ \\
\hline
\end{tabular}


BLINDNESS IN THE TERTIARY SECTOR: EXPLANATORY MODEL

\begin{tabular}{|c|c|c|c|}
\hline Family and peers & $\begin{array}{l}\text { External support } \\
\text { (Family and peers) }\end{array}$ & Refer the note & $\begin{array}{l}\text { Family and sighted peers' } \\
\text { support is extracted by } \\
\text { 'motivational influences' while } \\
\text { peers with visual impaired and } \\
\text { blind comes under the factor of } \\
\text { 'peer and physical support' }\end{array}$ \\
\hline External parties & Refer the note & $\begin{array}{l}\text { External } \\
\text { assistance }\end{array}$ & $\begin{array}{l}\text { The induce of "External parties" } \\
\text { is absorbed into "External } \\
\text { support } \\
\text { (Family and peer)" under } \\
\text { qualitative results. }\end{array}$ \\
\hline Instructional strategies & $\begin{array}{l}\text { Instructional } \\
\text { strategies }\end{array}$ & Refer the note & $\begin{array}{l}\text { Items related to instructional } \\
\text { strategies extracted by } \\
\text { 'motivational influences' and } \\
\text { 'support for learning' }\end{array}$ \\
\hline Motivation & Motivation to learn & $\begin{array}{l}\text { Motivational } \\
\text { influences }\end{array}$ & $\begin{array}{l}\text { Motivational influences } \\
\text { (intrinsic and extrinsic) play a } \\
\text { significant role. }\end{array}$ \\
\hline English and IT literacy & $\begin{array}{l}\text { English and IT } \\
\text { literacy }\end{array}$ & Refer the note & $\begin{array}{l}\text { Competency in English and IT } \\
\text { appears to have no direct } \\
\text { influence and is absorbed into } \\
\text { 'support for learning' }\end{array}$ \\
\hline & & $\begin{array}{l}\text { Access to } \\
\text { Information }\end{array}$ & \multirow{3}{*}{$\begin{array}{l}\text { Even though this study has } \\
\text { derived these three factors as } \\
\text { separate factors, these are } \\
\text { aligned with the conceptual } \\
\text { framework and qualitative } \\
\text { findings to a greater extent. }\end{array}$} \\
\hline & & $\begin{array}{l}\text { Peer and } \\
\text { physical support }\end{array}$ & \\
\hline & & $\begin{array}{l}\text { Support for } \\
\text { learning }\end{array}$ & \\
\hline
\end{tabular}

The factor labeled 'motivational influences' would have the highest significance loaded with 20 items. This factor can include self-motivation and self-judgment towards studies including the motivational support by internal (family) and external parties (teachers and peers) together with appropriate physical environment. Motivation to learn which is brought about by external parties and intrinsic self-motivation of the person is recognized by literature as a prime determinant of academic achievement of students with visual impairment and blindness. Relevance to these factors based on past literature is provided in Section F above.

Support for learning and support of external parties confirmed to play a significant role in academic advancement in the University for persons with visual impairment and blindness. The support of external parties includes both colleagues with visual impairment and blindness and the University community in general. As outlined in the literature review (see Table 8 ) these results also are in conformity with most past findings.

Although literature and the qualitative investigation points to 'physical infrastructure' as a specific factor that has an influence on academic achievement, the final results show that this point has been absorbed in to the factor labeled 'motivational influences'. Authors' experience and key informant interviews show that although the 
physical environment is not very supportive for independent mobility and also learning of persons with visual impairment and blindness, with acquaintance and familiarization influence of such issues on learning become marginal. This may be explained in terms of intimate social interactions between peers supported with the inherent culture of Sri Lanka.

While the importance of peers and physical support for academic achievement was highly recognized by the literature as well as by the key informant interviews, this study is also identified 'peers and physical support' as one factor for influencing education achievement of persons with visual impairment and blindness. Peer support in terms of academic (e.g., paraphrasing lectures, sharing notes), and social and emotional support (e.g., encouraging initiations for communication, talking about hobbies or interests) is found to be a positive impact of academic achievement. Provision of instrumental support (e.g., Laptop, Desktop, Recorder, Typewriter, Braille and Slate) in contrast (by the university or family/peers) is considered as one of the fundaments of inclusive education by the literature.

Access to information in terms of academic, financial and social through internet and smart phone along with English literacy is another novel factor derived from this study. Since no evidence in past literature has been found, it can be argued that English literacy and use of smart phone may not be equally important in some countries or some communities for access to information. However, access to internet for information is revealed adequately by past literature.

In summary, past literature and empirical evidence derived from key informant interviews clearly evidence that the derived five-factors of this study are valid and applicable towards academic success of the students with visual impairment and blindness. Accordingly, the derived five factors (five composite score data) can be used for parametric statistical analysis in future studies.

\section{Acknowledgements}

Authors acknowledge the World Bank assisted AHEAD (Accelerating Higher Education Expansion and Development) Research project on 'Quality of Life and Employability potential of Persons with Visual Impairment and Blindness in Sri Lanka' of the SLIIT Business School, for sponsoring this study and supporting in many respects. Authors also wish to thank the management and interview respondents of vocational training centres for providing valuable information, and the local and international intellectuals who are experts in their own fields for providing scholarly and practical insights during the model review process.

\section{Conflict of Interest Statement}

The authors declare no conflicts of interests. 


\section{About the Authors}

Professor Theekshana Suraweera, the founder Dean of SLIIT- Business School, is currently a Consultant Professor of the same institution. He is the Team Leader of World Bank sponsored AHEAD (Accelerating Higher Education Expansion and Development) Research Project on 'Socio-economic aspects of persons with Visual Impairment and Blindness in Sri Lanka' of SLIIT Business School. Previously, he served at University of Canterbury, New Zealand. His publication record exceeds 35 research papers in high quality local and international conferences and journals, including 'Journal of Small Business Management' and 'Disability and Society' with over 250 citations. His wide research interests include Disability Studies, Education and Social Development, Small Business and Information Systems Management.

Web: https://www.sliit.lk/faculty-of-business/staff/theekshana.s/ orcid.org/0000-0002-1756-7447

Professor Samantha Thelijjagoda is the Dean of SLIIT Business School, Sri Lanka and is currently a team member of the World Bank sponsored AHEAD Research Project on 'Socio-economic aspects of persons with Visual Impairment and Blindness in Sri Lanka'. He completed his postgraduate studies in Japan and was formally the Dean of Faculty of Graduate Studies and Research at SLIIT. He is a leading member of Computer Society of Sri Lanka, and holds professional memberships of IEEE, AIS and IET. His research interests range from IT applications and Social Studies, disability related studies, artificial intelligence, computational models of human language processing and human language technology. He has a strong publication record in peer reviewed local and international journals.

Web: https://www.sliit.lk/faculty-of-business/staff/samantha.t/ orcid.org/0000-0002-0548-1603

Professor Ruwan Jayathilaka is an Associate Professor at SLIIT Business School. He is currently serving as the Head, Department of Information Management, SLIIT Business School and the Coordinator of the SLIIT- MBA program. He is also a team member of the World Bank sponsored AHEAD Research Project of SLIIT Business School. He is the author of peer reviewed articles published in a number of international leading journals, including Applied Economics, Tourism Analysis, Tourism Review, PLOS ONE, BMC Public Health, Quality \& Quantity, Disability and Society, South Asia Economic Journal, Journal of the Korean Economy. His research interests are disability studies, poverty and vulnerability, econometric modeling, economic demography and social studies.

Web: https://www.sliit.lk/faculty-of-business/staff/ruwan.j/ orcid.org/0000-0002-7679-4164

Samanthi Bandara is currently the Specialized Research/Project Manager in Social Research Discipline for AHEAD project on 'Socio-economic aspects of persons with Visual Impairment and Blindness in Sri Lanka' of SLIIT Business School. She is a visiting lecturer at International Institute of Health Sciences. Previously, she served as a Consultant to the Presidential Secretariat. She also worked as a Health Economist to ADB 
and JETRO-Sri Lanka. Previously, she engaged as a research expert in managing public, private, regional, and internationally funded research projects while serving a researcher at Sri Lanka Institute of Policy Studies (IPS). Her publication history records for research papers in high quality local and international conferences and journals. She holds the Honorary Secretary position of Population Association of Sri Lanka (PASL). Her research interests are in population studies with special focus on disability studies.

Colinie Wickramarachchi is currently a Research Assistant for AHEAD Research Project on 'Socio-economic aspects of persons with Visual Impairment and Blindness in Sri Lanka' of SLIIT Business School. She graduated with a first-class honors with an outstanding academic award for Business Management. Previously, she worked as a finance intern for Central Bank of Sri Lanka. Her publication history records for research papers in high quality local and international conferences. Her research interests are disability studies, social studies, employment, and education.

Web: https://www.sliit.lk/faculty-of-business/staff/colinie.w/

Navodya Malshani, co-author of this research paper, is currently a final year undergraduate of BBA Special Honours degree at SLIIT Business School, Sri Lanka.

Nilupuli Nanayakkara, co-author of this research paper, is currently a final year undergraduate of BBA Special Honours degree at SLIIT Business School, Sri Lanka.

Tharushi Gunawardana, co-author of this research paper, is currently a final year undergraduate of BBA Special Honours degree at SLIIT Business School, Sri Lanka.

Erandi Yapa, co-author of this research paper, is currently a final year undergraduate of BBA Special Honours degree at SLIIT Business School, Sri Lanka.

\section{References}

20th Amendment: Constitution 2020. The Constitution of the Democratic Socialist Republic of Sri Lanka Parliament Secretariat

Abate T, 2020. Determinants of Students Tertiary Level Academic Performance in Ethiopia: A Case in University of Gondar. Journal of Education and Practice doi:10.7176/jep/11-22-04

AHEAD 2021. Sri Lanka Council of Visually Handicapped Graduates: Basic Data Collection. Sri Lanka Institute of Information Technology

Alberta, 1. 2002. Health and Life Skills: Instructional Strategies. https://education.alberta.ca/media/1477143/healthgi.pdf. Accessed 12 September 2021

Anne G, Danielsen, Oddrun S, Hetland J, Wold B, 2009. School-Related Social Support and Students' Perceived Life Satisfaction. The Journal of Educational Research 102: 303-320. doi: 10.3200/JOER.102.4.303-320

Bernard B, 1991. Fostering Resiliency in Kids: Protective Factors in the Family, School, and Community. https://www.wested.org/resources/fostering-resiliency-in-kids- 
protective-factors-in-the-family-school-and-community/\#. Accessed 14 October 2021

Bloom A, 1987. The Closing of the American Mind. New York: Simon and Schuster Bodaghi N, Cheong L, Zainab A, 2016a. Librarians Empathy: Visually Impaired Students' Experiences Towards Inclusion and Sense of Belonging in an Academic Library. The Journal of Academic Librarianship 42: 87-96. doi:10.1016/j.acalib.2015.11.003

Bodaghi N, Cheong L, Zainab A, Riahikia M, 2016b. Friendly Librarians. Information Development 33: 229-242. doi:10.1177/0266666916641178

Kannangara C, 1943. Sri Lanka Education Forum: Special Policy

Wickramaarachchi C, Suraweera T, Thelijjagoda S, Jayathilaka R 2021. An Operational Model of Managing Vocational Training for Persons with Visual Impairment and Blindness. 14th International Research Conference. General Sir John Kotelawala Defence University, Ratmalana, Sri Lanka

Carter E, Moss C, Asmus J, Fesperman E, Cooney M, Brock M, Lyons G, Huber H, Vincent B, 2015. Promoting Inclusion, Social Connections, and Learning Through Peer Support Arrangements. Teaching Exceptional Children, 48: 9-18. doi:10.1177/0040059915594784

Celeste M, Grum D, 2010. Social Integration of Children with Visual Impairment: A Developmental Model. Elementary Education 9

Central Bank of Sri Lanka 2020. Sri Lanka Socio Economic Data: Statistics Department Datta P, Palmer C, 2015. Insights Into the Support Services for Students with Vision Impairment. Australasian Journal of Special Education 39: 143-158. doi: $10.1017 /$ jse.2015.8

Davis B, 2021. What is the meaning of family background? MV Organizing. https://www.mvorganizing.org/what-is-the-meaning-of-family-background/.

Accessed 7 November 2021

Deci E, Ryan R, 2000. The "What" and "Why" of Goal Pursuits: Human Needs and the Self-Determination of Behavior. Psychological Inquiry 11: 227-268. doi:10.1207/s15327965pli1104_01

Edgerton J, Roberts L, Von Below S, 2012. Education and Quality of Life. Handbook of Social Indicators and Quality of Life Research

Fredricks J, Blumenfeld P, Paris A, 2004. School Engagement: Potential of the Concept, State of the Evidence. Home Health Care Management \& Practice 74: 79-85. doi: $10.1177 / 1084822315599954$

Ghenghesh P, 2014. The Relationship Between English Language Proficiency and Academic Performance of University Students - Should Academic Institutions Really be Concerned? International Journal of Applied Linguistics \& English Literature 4 doi:10.7575/aiac.ijalel.v.4n.2p.91

Haakma I, Janssen M, Minnaert A, 2018. Need Support in Students with Visual Impairments: Comparing Teacher and Student Perspectives. Frontiers in Education 2 doi:10.3389/feduc.2017.00071 
Hadidi M, Khateeb A, 2014. A Comparison of Social Support among Adolescents with and without Visual Impairments in Jordan: A Case Study from the Arab Region. Journal of Visual Impairment \& Blindness 108: 414-427. doi:10.1177/0145482x1410800506

Hijazi S, Naqvi S, 2006. Factors Affecting Students' Performance: A Case of Private College. Bangladesh e-Journal of Sociology 3: 1-10

Judge S, 2005. The Impact of Computer Technology on Academic Achievement of Young African American Children 20: 91-101

Kain V, 2016. Study Habits of Children with Visual Impairment. 1: 36-38

Kamal S, Asrar M, Younes M, Chishti A, 2014. Factors Affecting Academic Performance of Special Students: A Case of Peshawar District. SSRN Electronic Journal. doi:10.2139/ssrn.2755144

Lindsay S, McPherson A, 2012. Strategies for improving disability awareness and social inclusion of children and young people with cerebral palsy. Child Care Health Development 38: 809-816. doi: 10.1111/j.1365-2214.2011.01308

Luthar S, Cicchetti D, Becker B, 2000. The construct of resilience: a critical evaluation and guidelines for future work. Child Development 71: 543-562. doi:10.1111/14678624.00164

Maingi-Lore M, 2016. Factors Influencing Academic Performance of Students with Special Needs in Institutions of Higher Learning: the Case of Middle Level Colleges in Machakos Country. Kenya Mary Maingi-Lore a Research Project Report Submitted in Partial Fulfillment of the Research

Manitsa I, Doikou M, 2020. Social Support for Students with Visual Impairments in Educational Institutions: An Integrative Literature Review. British Journal of Visual Impairment doi:10.1177/0264619620941885

Masten A, 2001. Ordinary magic: Resilience processes in development. American Psychologist 56: 227-238. doi: 10.1037//0003-066x.56.3.227

Mishra P, Pandey C, Singh U, Gupta A, Sahu C, Keshri A, 2019. Descriptive Statistics and Normality Tests for Statistical Data. Ann Card Anaesth 22: 67-72. doi:10.4103/aca.ACA_157_18

Morelle M, Tabane R, 2019. Challenges experienced by learners with visual impairments in South African township mainstream primary schools. South African Journal of Education 39: 1-6. doi:10.15700/saje.v39n3a1615

Nees M, Berry L, 2013. Audio Assistive Technology and Accommodations for Students with Visual Impairments: Potentials and Problems for Delivering Curricula and Educational Assessments. Performance Enhancement \& Health 2: 101-109. doi:10.1016/j.peh.2013.08.016

Nishanthi R, 2018. The Importance of Learning English in Today World. International Journal of Trend in Scientific Research and Development 3: 871-874. doi:10.31142/ijtsrd19061 
Otyola W, Kibanja G, Mugagga A, 2017. Challenges Faced by Visually Impaired Students at Makerere and Kyambogo Universities. Makerere Journal of Higher Education 9: 75-75. doi:10.4314/majohe.v9i1.6

Pathrose A, Ramaa P, 2020. Relation of Academic Stress on Academic Achievement of Visually Impaired Students. 8. doi:10.25215/0802.119

Pavri S, Monda-Amaya L, 2001. Social Support in Inclusive Schools: Student and Teacher Perspectives. Exceptional Childre. 67: 391-411. doi: 10.1177/001440290106700307

Santos G, Ramos E, 2019. ICT Literacy and School Performance. 18: 19-39

Senjam S, 2019a. Assistive Technology for People with Visual Loss. Delhi Journal of Ophthalmology. 30 doi:10.7869/djo.496

Senjam S, 2019b. Assistive Technology for Students with Visual Disability: Classification Matters. Kerala Journal of Ophthalmology. 31: 86-86. doi:10.4103/kjo.kjo_36_19

Shahzadi E, Ahmad Z, 2011. A Study on Academic Performance of University Students. 8th International Conference on Recent Advances in Statistics. 255-268. doi:10.13140/2.1.3949.3126

Spiel C, Schwartzman S, Busemeyer M, Cloete N, Drori G, Lassnigg L, Schober B, Schweisfurth M, Verma S, 2018. The Contribution of Education to Social Progress. International Panel on Social Progress 753-778. doi:10.1017/9781108399661.006

Spinath B, 2012. Academic Achievement, Elsevier Inc

Suraweera T, Wickramarachchi C, Dewage N, Gunawardana M, Nanayakkara T, Yapa N, Handapangoda R, Factors Affecting Academic Performance of People with Visual Disabilities in the Tertiary Sector. Proceedings of Sri Lanka Institute of Information Technology International Conference on Advancements in Sciences and Humanities. 261-266

Suraweera T, Dunuwila V, 2019. Challenges of Social Inclusion of the Visually Impaired and Blind Persons in the Sri Lankan Workplace. 7th Peradeniya International Economics Research, Department of Economics and Statistics, Faculty of Arts University of Peradeniya, Sri Lanka

Suraweera T, Jayathilaka R, Thelijjagoda S, 2021. A Nightmare in a 'Darker' World: Persons with Blindness under the Sri Lanka's COVID-19 Shutdown. Disability \& Society doi:10.1080/09687599.2021.1927671

UGC, 2020. Sri Lanka University Statistics: Educational Indicators 1990-2020. Graduate Output: University Grants Commission, Sri Lanka

UN General Assembly 2007. Convention on the Rights of Persons with Disabilities: Resolution Adopted by the General Assembly. A/RES/61/106

UNESCO, 2000. The Dakar Framework for Action.

UNESCO, 2019. Education transforms lives [Online]. United Nation Educational, Scientific and Cultural Organization. https://en.unesco.org/themes/education/. Accessed 23 August 2021

United Nations, 2006. United Nations Convention on the Rights of Persons with Disabilities. Article 9 Accessibility. 
https://www.un.org/development/desa/disabilities/convention-on-the-rights-ofpersons-with-disabilities/article-9-accessibility.html. Accessed 29 November 2021 United Nations, 2015. Envision2030: 17 Goals to Transform the World for Persons with Disabilities United Nations. https://www.un.org/development/desa/disabilities/envision2030.html Accessed 12th November 2021

West J, Houghton S, Taylor M, Ling P, 2004. The Perspectives of Singapore Secondary School Students with Vision Impairments towards their Inclusion in Mainstream Education. Australian Journal of Special Education 28: 18-27. doi: 10.1017/S1030011200025100

Yihun S, Belay M, 2020. The Challenges and Opportunities of Visually Impaired Students in Inclusive Education: The Case of Bedlu. Journal of Pedagogical Research 4: 112124. doi:10.33902/jpr.2020060437 
Theekshana Suraweera, Samanthi Bandara, Colinie Wickramarachchi, Navodya Dewage,

Tharushi Gunawardana, Nilupuli Nanayakkara, Erandi Yapa, Samantha Thelijjagoda, Ruwan Jayathilaka

Creative Commons licensing terms

Authors will retain the copyright of their published articles agreeing that a Creative Commons Attribution 4.0 International License (CC BY 4.0) terms will be applied to their work. Under the terms of this license, no permission is required from the author(s) or publisher for members of the community to copy, distribute, transmit or adapt the article content, providing a proper, prominent and unambiguous attribution to the authors in a manner that makes clear that the materials are being reused under permission of a Creative Commons License. Views, opinions and conclusions expressed in this research article are views, opinions and conclusions of the author(s). Open Access Publishing Group and European Journal of Special Education Research shall not be responsible or answerable for any loss, damage or liability caused in relation to/arising out of conflict of interests, copyright violations and inappropriate or inaccurate use of any kind content related or integrated on the research work. All the published works are meeting the Open Access Publishing requirements and can be freely accessed, shared, modified, distributed and used in educational, commercial and non-commercial purposes under a Creative Commons Attribution 4.0 International License (CC BY 4.0). 